\title{
The By-Products of Prickly Pear Processing in Broiler Feed: Case of Dehydrated Husks and Cake
}

Imene Cherif

University of chadli Bendjedid El Tarf 36000 Algeria

Rafik Arbouche

University of Ghardaïa 47000

yasmine Arbouche

Universite Ferhat Abbas Setif 1

Achour Mennani

University of Ferhat Abbas Setif 1

Fodil Arbouche ( $\square$ arbouchefodil@yahoo.fr)

Department of Agronomy, Faculty of Life and Earth Sciences, University of Ghardaia, Ghardaia 47000 Algeria;

https://orcid.org/0000-0002-3553-3849

\section{Research}

Keywords: food, envelopes, prickly pear, performance, broiler, meal

Posted Date: January 5th, 2021

DOI: https://doi.org/10.21203/rs.3.rs-136872/v1

License: (c) This work is licensed under a Creative Commons Attribution 4.0 International License. Read Full License 


\section{Abstract}

Background: The utilization of agro-industrial by-products is a potential substitution of imported raw materials in broiler feed formulas for developing countries. This study aims to determine the effects of substituting prickly pear husks for maize and prickly pear seed cake for soybean meal on the production performance, slaughter characteristics, and chemical composition of broiler meat.

Materials and methods: Two hundred day-old chicks of equal sex ratio (1:1) of Big Fast strain, weighing on average $37 \pm 2 \mathrm{~g}$, were randomly divided into 4 homogeneous groups of 50 subjects each. Each group was subdivided into 10 packs of 05 animals, banded and numbered. The rations distributed with a substitution rate of $0,10 \%, 20 \%$, and $30 \%$ of maize and soybean meal by dehydrated husks and prickly pear cake were randomly distributed through the different groups.

Results: Average daily gains and body weights at 48 days were improved $(p<0.05)$ for the $10 \%$ and $20 \%$ groups and the $30 \%$ group performed identically to the control. Cold carcass yield was optimal for $10 \%$ and $20 \%$ groups. The liver weight of the experimental groups decreased significantly $(p<0.05)$ while that of the gizzards increased significantly $(+24$ points). The meat protein rate evolved proportionally to the substitution rate, in contrast to the fat rate, which was depreciated by up to -1.08 points for the $30 \%$ group compared to the control.

Conclusion: The incorporation of prickly pear processing by-products into broiler feed at rates of $10 \%$ and $20 \%$ improves zootechnical performance, carcass yields, and the chemical composition of the meat.

\section{Background}

In Algeria, the costs of animal production are dependent on imports of the raw materials used in food formulae, thus generating meat products influenced by the parity of the Algerian dinar with foreign currencies. As pointed out by Guermah et al [1], the feeding of the domestic animal represents $70 \%$ of the cost price of the products produced and remains under the influence of the prices posted by the world stock exchanges. The latter leads to inflation, making the prices of meat products beyond the reach of the poorest populations. The use of agricultural and agro-industrial by-products in domestic animal rations [2-7] is one way of regulating or even lowering the cost price of these products. The use of by-products from the processing of prickly pear (Opuntia ficus-indica L. mill) remains an alternative to be considered, given that this species is well represented in arid and semi-arid regions of the country $(55,671 \mathrm{ha}$, [8]), is well adapted to a warm environment [9] and its fruits are used in local culinary customs and the cladodes consumed by the animals living there [10].

The prickly pear can be considered as a versatile crop [11] and as a substitute food due to its efficiency in converting water into the dry matter [12-15], thus ensuring a balance of digestible energy in pet food.

Prickly pear (FB) is eaten fresh [16], the pericarp accounts for $33 \%$ to $55 \%$, the pulp for $45 \%$ to $67 \%$ and the seeds for $2 \%$ to $10 \%$ [17]. The fruit is also used for the production of juice, jellies, jams, vinegar, and oil from the seeds. This agro-industry generates by-products made up of husks, seeds, and oilcake, which are a source of environmental pollution because they are not valorized. According to Kenny [18], the yield per hectare is between 12 and 30 tones. If we consider that half of the planted area, i.e. 27836 ha for an average yield of $21 \mathrm{~T} /$ ha of fruit, is taken care of by the agro-industry, the by-products generated in envelopes (pericarps) (44\%) would be 257205 T, in seeds $(6 \%)$ of 35073 T translatable into oilcake (97\%) of $34021 T$. This total quantity of $291226 \mathrm{~T}$, is without context not negligible if it is valorized in animal feed.

The use of these by-products in poultry farming remains very little studied. Moula et al [19], in their study, used the whole fruit in Algeria in the same way as Badr et al [20] in Egypt, while Regab [21] experimented with the fruit envelope with the addition of enzymes. 
For our part, our study aims to experiment with the by-products of the processing of Opuntia fruits (seed casings and cakes) in the diet of broilers.

\section{Materials And Methods}

The present study was conducted after approval of Institutional Animal Ethics Committee laboratory of Agriculture departement of Ghardaia University, Algeria.

\section{Animals, diets, and experimental protocol}

The trial was carried out at a poultry production unit in the municipality of El Kouif Wilaya of Tébessa (Algeria) in a building with a surface area of $80 \mathrm{~m}^{2}$, fitted with thermal insulation made of polystyrene panels.

The study was carried out over a rearing period of 48 days, in a closed henhouse equipped with pad-cooling fans and humidifiers ensuring good ambient conditions. The litter consisted of sieved wood shavings.

Two hundred day-old chicks of equal sex ratio (1:1), of Big Fast strain, weighing on average $37 \pm 2 \mathrm{~g}$, were randomly divided into 4 homogeneous batches of 50 subjects each. Each batch was subdivided into 10 packs of 05 animals, banded and numbered, forming a control batch and three experimental batches.

The seed cakes and dehydrated prickly pear husks were supplied by an agro-industrial processing unit producing vinegar and prickly pear oil, located in the commune of Sidi fredj Wilaya of Souk-Ahras in south-eastern Algeria. The chemical composition of these two by-products is shown in Table 1.

Table 1. Chemical composition of prickly pear processing by-products in \% DM

\begin{tabular}{|c|c|c|}
\hline & seed cake & Dehydrated envelopes \\
\hline Dry matter (DM) & 94,3 & 94,5 \\
\hline Organic matter & 98.3 & 91.3 \\
\hline Total nitrogenous materials & 8.8 & 5.6 \\
\hline Raw cellulose & 55 & 52.3 \\
\hline Fats and fats & 2.7 & 4 \\
\hline Mineral materials & 1.7 & 8.7 \\
\hline Non-nitrogenous extractive & 31,7 & 29,4 \\
\hline Gross energy (kcal/kg of DM) & 4443 & 4166 \\
\hline Metabolizable energy (kcal/kg of DM) * & 1818 & 1710 \\
\hline Lysine (g/100g protein) & 0,54 & 0,98 \\
\hline Methionine (g/100g protein) & 0,32 & 0,52 \\
\hline Cystine (g/100g protein) & 0,31 & 0,62 \\
\hline \multicolumn{3}{|c|}{$\begin{array}{l}\text { * estimated according to the formula of Carpenter and Clegg (1956) with } M E(\mathrm{kcal} / \mathrm{kg} D M)=35.3 \times C P(\%)+79.5 \times F \\
(\%)+40.6 \times N N E(\%)+199\end{array}$} \\
\hline \multicolumn{3}{|c|}{ (ME : Metabolizable energy, CP : Crude protein, F: Fat, NNE: Non-nitrogenous extractive). } \\
\hline
\end{tabular}


Using the WUFFDA software for broiler feed formulation, four rations were constituted, with $0 \%$ (control feed), $20 \%$; $30 \%$, and $40 \%$ substitution of soya meal by prickly pear seed cake and maize by their husks for the different rearing phases (Table 2). Rations were distributed randomly for the four broiler groups.

For the first ten days and thanks to gas-powered cattle raisers, a temperature varying between 36 and $38^{\circ} \mathrm{C}$ was maintained, as well as a 24-hour illumination, which was then reduced to 12 hours during the day and 6 hours at night. 
Table 2. Formulas (kg/100 kg feed) of starter (1-20 days), grower (21-33 days), and finisher (34-48 days) feed distributed to chickens according to the rate of substitution of corn by prickly pear husks and soybean meal by prickly pear seed

cake

$(\underline{\mathrm{FB}})$.

Start Growth Finishing

$\begin{array}{lllllllllllll}\text { Substitution rate } & 0 & 10 & 20 & 30 & 0 & 10 & 20 & 30 & 0 & 10 & 20 & 30\end{array}$

$(\%)$

\section{Ingredients}

$\begin{array}{lllllllllllll}\text { Corn } & 61 & 55 & 49 & 43 & 64 & 58 & 51 & 45 & 70 & 63 & 56 & 49 \\ \begin{array}{l}\text { Envelopes from } \\ \text { FB }\end{array} & 0 & 06 & 12 & 18 & 0 & 06 & 13 & 19 & 0 & 07 & 14 & 21\end{array}$

\begin{tabular}{lllllllllllll} 
Soya cake & 30 & 27 & 24 & 21 & 27 & 24 & 22 & 19 & 21 & 19 & 17 & 15 \\
\hline FB seed cake & 0 & 03 & 06 & 09 & 0 & 3 & 5 & 08 & 0 & 02 & 4 & 06 \\
\hline From milling & 6 & 6 & 6 & 6 & 6 & 6 & 6 & 6 & 6 & 6 & 6 & 6 \\
$\begin{array}{l}\text { Bi-calcium } \\
\text { phosphorus }\end{array}$ & 1,2 & 1,2 & 1,2 & 1,2 & 1,2 & 1,2 & 1,2 & 1,2 & 1,2 & 1,2 & 1,2 & 1,2 \\
\hline CMV & 1,25 & 1,25 & 1,25 & 1,25 & 1 & 1 & 1 & 1 & 1 & 1 & 1 & 1 \\
\hline L-Lysine & 0,15 & 0,15 & 0,15 & 0,15 & 0,5 & 0,5 & 0,5 & 0,5 & 0,5 & 0,5 & 0,5 & 0,5 \\
\hline DL-Methionine & 0,4 & 0,4 & 0,4 & 0,4 & 0,3 & 0,3 & 0,3 & 0,3 & 0,3 & 0,3 & 0,3 & 0,3
\end{tabular}

\section{Nutrient content in \% DM}

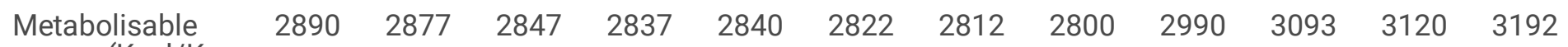
energy $(\mathrm{Kcal} / \mathrm{Kg}$

of MS)

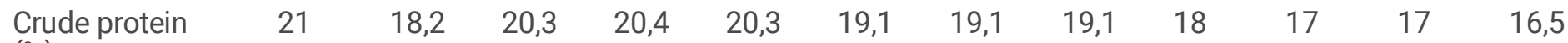

(\%)

\begin{tabular}{lllllllllllll} 
Fat content (\%) & 2,8 & 5,4 & 5,2 & 5,0 & 2,9 & 3,2 & 5,1 & 4,9 & 3,0 & 5,0 & 4,9 & 4,7 \\
$\begin{array}{l}\text { Mineral } \\
\text { materials (\%) }\end{array}$ & 3 & 3,5 & 3,8 & 4,09 & 2,7 & 3,4 & 3,7 & 4,1 & 2,9 & 3,2 & 3,6 & 4 \\
\hline $\begin{array}{l}\text { Raw cellulose } \\
\text { (\%) }\end{array}$ & 3,0 & 8,7 & 13,7 & 17,7 & 2,9 & 8,6 & 13,6 & 17,5 & 2,8 & 8,4 & 12,8 & 17,3
\end{tabular}

$(\%)$

\begin{tabular}{lllllllllllll} 
Lysine (\%) & 1,20 & 9,62 & 8,66 & 7,92 & 1,38 & 8,82 & 8,12 & 7,16 & 1,22 & 7,5 & 6,81 & 6,11 \\
\hline Methionine (\%) & 0,72 & 2,78 & 2,53 & 2,27 & 0,60 & 2,68 & 2,44 & 2,18 & 0,57 & 2,38 & 2,24 & 2,02
\end{tabular}

Water and feed were distributed ad-libitum and the refusal was weighed daily. Vaccination against Newcastle disease and infectious bronchitis was carried out at the 7th and 21 st breeding farms and against Gumboro disease at 14 days of age (no booster vaccination). An anticoccidial was administered at 17 and 34 days of age for two successive days in drinking water. The animals were individually weighed at placement, 10; 20; 33, and 48 days of age. Mortality was recorded daily throughout the entire experiment. 
At the end of the rearing, 30 chickens taken at random from each batch were sacrificed. The live weight, the weight of the warm and cold carcass, legs, head, feathers, gizzard, viscera, and liver were weighed. The average daily gain (ADG), average daily intake (ADI), and feed and liver were weighed. The average daily gain (ADG), average daily intake (ADI), and feed conversion ratio (FCR) were calculated. At 24 hours post-mortem, the pH was measured by direct insertion $(\sim 2 \mathrm{~cm}$ deep) of the electrode of a pH meter into the pectoral muscle of quails according to the method of EL Rammouz, [23]. Ash, protein, and fat content were determined and calculated according to the Aoac methods [24].

\section{Statistical analysis}

Descriptive statistics and single-factor analysis of variance (ANOVA) were performed with the SPSS software (version 18, 2008) for the analysis of performance, slaughter parameters, and meat chemical composition. The post hoc test by the application of the S.N.K (Student- Newman- Keules) and Duncan test, to estimate the significance or homogeneity between the different subsets (test of comparison between the means). The differences were considered significant with a $5 \%$ risk of error.

\section{Results}

No mortality was recorded during the whole breeding in all groups. During the start-up phase, the $10 \%$ group recorded significantly $(p<0.05)$ higher weights at 10 days and 20 days than the other groups with $+24 \mathrm{~g}$ and $+51 \mathrm{~g}$ respectively (Table 3). 
Table 3. Changes in weight growth and $A D G(g / d / s u b j e c t)$ during the start-up, growth, and finishing phases as a function of substitution rates.
0
10
20
30
SEM
p

\section{Start-up phase}

Initial weight $(\mathrm{g})$

37

37

37

37

Weight at $10 \mathrm{~d}(\mathrm{~g})$

$137^{\mathrm{b}}$

$161^{\mathrm{a}}$

$114^{d}$

$128^{\mathrm{C}}$

2.19

0.001

ADG 1-10 (g/d/subject)

$11,1^{\mathrm{b}}$

$13,8^{\mathrm{a}}$

$8,6^{d}$

$10,1^{\mathrm{c}}$

0.25

0.02

Weight at $20 \mathrm{~d}(\mathrm{~g})$

$438^{b}$

$489^{a}$

$412^{c}$

$407^{c}$

9,67

0.01

ADG 11-20(g/d/subject)

$33,4^{\mathrm{b}}$

$36,4^{\mathrm{a}}$

$33,1^{\mathrm{b}}$

$31,0^{b}$

1,13

0,001

ADG 1-20 (g/d/subject)

$21,1^{b}$

$23,8^{a}$

$19,8^{c}$

$19,5^{\mathrm{c}}$

0.36

0.01

\section{Growth phase}

Weight at $33 \mathrm{~d}(\mathrm{~g})$

$1032^{b}$

$1139^{a}$

$1020^{b}$

$987^{b}$

22,21

0.03

ADG 21-33 (g/d/subject)

$49,5^{b}$

$54,2^{\mathrm{a}}$

$50,6^{b}$

$48,3^{b}$

1.48

0.015

\section{Finishing phase}

Weight at 48 days $(\mathrm{g})$

ADG 34-48 (g/d/subject)

ADG 1-48 (g/d/subject) $2003^{b}$

$69,49^{b}$

$39,7^{\mathrm{b}}$

The indices indicate the period in days over which this paran the same line indicates a significant difference between diets $(P<0.05)$.

The same trend was recorded for the ADG 1-10d $(+2.7 \mathrm{~g} / \mathrm{d} / \mathrm{subject})$ and the ADG 11-20d (+3 g/d/subject) respectively, as well as for the ADG 1-20d which, during the whole start-up phase, showed a significant difference $(p<0.05)$ of +2.7 $\mathrm{g} / \mathrm{d} /$ subject with the control and $+4.2 \mathrm{~g} / \mathrm{d} /$ subject with the other experimental groups.

During the growth phase, the $10 \%$ substitution rate of soybean meal and maize impregnated a significant optimization $(p<0.05)$ of the weight at 33 days as well as of the ADG 21-33d with a difference of $+126 \mathrm{~g}$ and $+8.7 \mathrm{~g} / \mathrm{d} /$ subject respectively compared to the average of the other batches. The latter being significantly similar.

In the finishing phase, the $30 \%$ batch took a minimum value $(p<0.05)$ in live weight at 48 days and ADG $34-48 d$ compared to the other batches, the $20 \%$ batch recorded higher results than the control batch while the $10 \%$ batch with $2225 \mathrm{~g}$ remained significantly dominant $(p<0.05)$, displaying an optimal ADG 34-48d of $77.5 \mathrm{~g} / \mathrm{d} / \mathrm{subject}$. The ADG $1-48 \mathrm{~d}$ of the $10 \%$ and $20 \%$ batches showed a higher value than the control batch, while the result of the $30 \%$ batch was identical to the control batch.

The average daily intakes of the experimental batches showed less significant results compared to the control lot during the first ten days with a difference of -5 points (Table 4). 


\begin{tabular}{|c|c|c|c|c|c|c|}
\hline & 0 & 10 & 20 & 30 & SEM & $\mathrm{p}$ \\
\hline \multicolumn{7}{|c|}{ Average daily intake (g/subject) } \\
\hline From 1 to 10 days & $270^{a}$ & $265^{\mathrm{b}}$ & $263^{b}$ & $263^{b}$ & 3,51 & 0,01 \\
\hline From 11 to 20 days & $511^{\mathrm{a}}$ & $513^{a}$ & $504^{b}$ & $510^{a}$ & 6.82 & 0.01 \\
\hline From 21 to 33 days & 1500 & 1490 & 1488 & 1487 & 10.24 & 0.3 \\
\hline From 34 to 48 days & $2844^{b}$ & $2869^{a}$ & $2870^{a}$ & $2846^{b}$ & 19.56 & 0.01 \\
\hline From 1 to 48 days & $5125^{b}$ & $5137^{a}$ & $5125^{b}$ & $5106^{c}$ & 53.8 & 0.02 \\
\hline \multicolumn{7}{|c|}{ Consumption index $(g / g)$} \\
\hline From 1 to 10 days & $2.7^{b}$ & $2.1^{\mathrm{c}}$ & $3.4^{\mathrm{a}}$ & $2.9^{b}$ & 0,253 & 0,001 \\
\hline From 11 to 20 days & $1.7^{b}$ & $1.6^{\mathrm{b}}$ & $1.7^{\mathrm{b}}$ & $1.9^{\mathrm{a}}$ & 0.566 & 0.01 \\
\hline From 21 to 33 days & 2.5 & 2.3 & 2.4 & 2.5 & 0.292 & 0.381 \\
\hline From 34 to 48 days & $2.9^{a}$ & $2.6^{\mathrm{b}}$ & $2.7^{b}$ & $2.9^{a}$ & 0.127 & 0.040 \\
\hline From 1 to 48 days & $2,6^{a}$ & $2,3^{b}$ & $2,4^{b}$ & $2,6^{a}$ & 0.132 & 0.010 \\
\hline
\end{tabular}

Between day 11 and day 20, the substitution of soybean meal and maize produced a depreciation of the group's average daily intake of $20 \%$ of $-10 \mathrm{~g}$ compared to the other groups that showed similar results. It can also be noted that during the $34-48$ days interval, the $10 \%$ and $20 \%$ groups showed identical and superior results to the control groups and $30 \%$, which took a mean value of $2845 \mathrm{~g}$ impregnating a mean difference of $-24 \mathrm{~g}$ with respect to the witness. The entire farm was characterized by the influence of the substitution of soy and maize meal by prickly pear seed cake and their envelopes on the $10 \%$ group, giving it optimization of the average daily intake, a devaluation of this parameter for the $30 \%$ group and an intermediate and identical result for the $20 \%$ and control groups.

Between the 34th and 48th day and from the $1^{\text {st }}$ to the 48th day, the consumption indices of the $10 \%$ and $20 \%$ groups of substitution of soybean meal by seed cake and maize meal by prickly pear husks were significantly similar and the least expressive $(p<0.05)$ compared to the control groups and $30 \%$.

The incorporation of prickly pear seed cake and husks in the broiler diet does not affect the weight of the viscera, head, legs, and feathers (Table 5). 
Table 5. Changes in slaughter parameters and meat chemistry as a function of the substitution rate

\begin{tabular}{|c|c|c|c|c|c|c|}
\hline & 0 & 10 & 20 & 30 & SEM & $\mathrm{p}$ \\
\hline \multicolumn{7}{|l|}{ Slaughter parameters } \\
\hline Live weight(g) (Pv) & $2009^{b}$ & $2221^{a}$ & $2052^{a b}$ & $1990^{b}$ & 119,1 & 0,019 \\
\hline Hot carcass weight (g) & $1406^{c}$ & $1597^{a}$ & $1487^{b}$ & $1398^{c}$ & 41,38 & 0,019 \\
\hline Hot carcass yield \% & $69,9^{b}$ & $72,0^{\mathrm{a}}$ & $72,5^{a}$ & $70,2^{b}$ & 0,12 & 0,011 \\
\hline Cold carcass weight (g) & $1265^{c}$ & $1494^{a}$ & $1391^{b}$ & $1222^{d}$ & 44,1 & 0,01 \\
\hline Cold carcass yield\%. & $63 b$ & $67,3^{a}$ & $67,8^{a}$ & $61,4^{\mathrm{C}}$ & 1,87 & 0,01 \\
\hline Visceral weight(g) & 239 & 236 & 235 & 240 & 4,1 & 0,88 \\
\hline Head weight(g) & 67 & 66 & 68 & 69 & 7,84 & 0,255 \\
\hline Leg weight(g) & 100 & 98 & 110 & 100 & 11,63 & 0,353 \\
\hline Weight Feather (g) & 147 & 146 & 146 & 147 & 11,03 & 0,817 \\
\hline Weight liver(g) (Pf) & $53^{a}$ & $47^{b}$ & $45^{\mathrm{b}}$ & $46 b$ & 7,82 & 0,034 \\
\hline $\mathrm{Pf} / \mathrm{Pv}$ ratio $(\%)$ & $2,6^{\mathrm{a}}$ & $2,1^{b}$ & $2,2^{b}$ & $2,3^{b}$ & 0,56 & 0,014 \\
\hline Gizzard weight(g) $(\mathrm{Pg})$ & $58^{b}$ & $85^{a}$ & $82^{a}$ & $80^{a}$ & 11,06 & 0,029 \\
\hline $\mathrm{Pg} / \mathrm{Pv}$ ratio (\%) & $2,9^{b}$ & $3,8^{a}$ & $3,9^{a}$ & $4,0^{\mathrm{a}}$ & 0,87 & 0,021 \\
\hline \multicolumn{7}{|c|}{ Chemical composition of the meat } \\
\hline $\mathrm{pH}$ & $6,34^{\mathrm{a}}$ & $6,31^{\mathrm{a}}$ & $6,36^{\mathrm{a}}$ & $6,23^{b}$ & 0,034 & 0,01 \\
\hline Crude protein content & $16,36^{\mathrm{b}}$ & $18,39^{a}$ & $18,50^{\mathrm{a}}$ & $18,77^{a}$ & 0,61 & 0,004 \\
\hline Fat content & $3,06^{\mathrm{a}}$ & $2.87^{\mathrm{ab}}$ & $2,56^{b}$ & $1,98^{\mathrm{c}}$ & 0,183 & 0,001 \\
\hline Mineral content & 0,88 & 0,98 & 0,92 & 0,94 & 0,148 & 0,267 \\
\hline
\end{tabular}

The hot carcass weights and yields of the $10 \%$ and $20 \%$ groups had optimal values $(p<0.05)$ compared to the control and the $30 \%$ group, which showed similar results $(p<0.05)$. The weights of cold carcasses were significantly different $(p<0.05)$ between all the groups with the supremacy of the $10 \%$ group inducing significantly similar yields $(p<0.05)$ and optimal for the $10 \%$ and $20 \%$ groups with a difference of about +4 points with the control. The $30 \%$ group recorded a minimum value.

The incorporation of FB seed cake and dehydrated husks resulted in a significant $(p<0.05)$ decrease in liver weight of the experimental groups with a similar mean value of $46.5 \mathrm{~g}$, resulting in a difference of $-6.5 \mathrm{~g}$ with respect to the control. The same observation was noted for the Pf/Pv ratios. On the other hand, the gizzard weights had an optimal and similar value for the experimental batches (average $82.3 \mathrm{~g}$ ), resulting in a significant difference $(p<0.05)$ of

$+24.3 \mathrm{~g}$ with respect to the control for $\mathrm{Pg} / \mathrm{Pv}$ ratios expressing the same trend. 
The $\mathrm{pH}$ of the meat at 24 hours post mortem, for the $10 \%$ and $20 \%$ groups were not influenced by the substitutions, which took on the same value with respect to the control, while the $30 \%$ group recorded a minimal result with respect to all the other groups. The experimental groups took significantly similar $(p<0.05)$ and maximum protein values, imparting a significant difference of $+2.19 \mathrm{~g}$ compared to the control. The mineral matter content was not influenced by the incorporation of FB seed cake and seed envelopes.

\section{Discussion}

The incorporation of the by-product of prickly pear processing (husks) and the by-product of oil extraction from BF seeds (oilcake) did not cause mortality in the experimental groups as reported by Badr et al [20] in Cobb chickens fed BF husks and Bakr et al [25] in rabbits fed BF zest. However, Moula et al [19], on broilers fed with 10\% prickly pear cladodes in the diet, found a mortality rate of $10 \%$, while Ragab [21] found a mortality rate of $3.3 \%$ in quails fed on diets containing $15 \%$ prickly pear shells.

The incorporation of FB fig seed husks and seed cakes at a rate of $10 \%$ and $20 \%$ in the feed of broiler chickens has led to an increase in live weight and ADG. This is in line with the results found by Badr et al [20], who found an improvement in weight performance due to the substitution of maize by FB envelopes of 5-15\% in Cobb broilers. However, Moula et al [19] for a $5 \%$ and $10 \%$ incorporation of FB cladodes in the broiler feed, observed no significant effect on body weight and ADG, in contrast to Ragab [26] who found in Hy-Line W-36 cocks fed with FB envelopes, a non-significant effect on body weight at 70 days but a positive effect on ADG. As in quails, Ragab [21] found that the incorporation of $15 \%$ and $30 \%$ FB envelopes had no influence on body weight and ADG, while in rabbits, Hassan et al [27] reported final weights and ADG with a ration containing $25 \%$ and $50 \%$ FB envelopes, These results contradict those reported by El-Neney et al [28] who found that a $20 \%$ and $30 \%$ incorporation of FB envelopes resulted in a significant increase in live weight. In fattening sheep, Islam et al[29] and Aware et al [30] reported a positive effect on body weight with incorporation rates of $60 \%$ and $80 \%$. Throughout the rearing period, the substitution of maize and soybean meal by prickly pear husks and meals respectively had a significant effect on average daily intake and feed conversion of broilers for the $10 \%$ and $20 \%$ groups. For their part, Badr et al [20] observed in Cobb chickens fed rations containing 5\%, 10\% and 15\% FB envelopes, average daily intakes, and lower consumption indices than for the control, as did El-Neney et al [28] for the incorporation of FB envelopes and Zeedan et al [31] for the incorporation of FB cladodes, and in rabbits at levels of $10 \%, 20 \%$, and $30 \%$.

The incorporation of prickly pear husks and cakes at a rate of $10 \%$ and $20 \%$ in the feed for broilers has led to an increase in the weight of hot and cold carcasses, and livers and gizzards but had no significant effect on other slaughter parameters, in contrast to the findings of Regab[26] in male chicks of line W-36 and Regab [21] in quails, which recorded no influence of the incorporation of FB envelopes on the slaughter parameters. However, Badr et al [20] found that at an incorporation rate of $5 \%, 10 \%$, and $15 \%$ ), a significant influence on carcass and offal weights was observed. In rabbits, Abu Shammalah [32] found that the use of FB envelopes in rabbit rations influences carcass characteristics. The crude protein content of the meat increased while the fat content decreased, in proportion to the rates of incorporation of BF envelopes in the rabbit ration, in line with the results reported by El-Neney et al [28] and Zeedan et al [31]. These results remain in contradiction with those of Regab [21,26] and Moula et al [19].

\section{Conclusion}

The incorporation of prickly pear husks and cakes in the feed of broiler chickens at rates of $10 \%$ and $20 \%$ improves zootechnical performance, carcass yields, and the chemical composition of the meat.

\section{Declarations}

\section{Acknowledgements}

Page $10 / 13$ 
Not applicable.

\section{Authors' contributions}

IC prepared the ground conditions and collected the data. RA revised the manuscript. YA performed the analysis of the data. AM prepared the diets and the chemical analyses. FA designed the study and drafted. All authors have read and approved the final manuscript.

\section{Competing interests}

The authors declare that they have no competing interests.

\section{Consent for publication}

Not applicable.

\section{Ethics approval}

The present study was conducted after approval of Institutional Animal Ethics Committee laboratory of Agriculture departement of Ghardaia University, Algeria.

\section{Availability of data and materials}

The datasets analyzed in the present study are available from the corresponding author on reasonable request.

\section{References}

1. Guermah, H., Maertens, L. and Berchiche, M. Nutritive value of brewers' grain and maize silage for fattening rabbits. World Rabbit Sci., 2016; 24: 183-189.

2. Arbouche, R., Arbouche, F., Arbouche, H.S. and Arbouche, Y. Nutritional value of oilseed in ruminant feed: Case of apricot kernel and its cake. Res. Rural Dev., 2007; 19: 189.

3. Arbouche, R., Arbouche, F., Arbouche, H.S. and Arbouche, Y. Effects on growth performance of the incorporation of apricot kernel cake in the broiler ration. med. Vet 2012, 163(10): 475-479.

4. Arbouche, R., Arbouche, F., Arbouche, H.S. and Arbouche, Y. Effects of the nature of the nitrogen supplement (apricot kernel cake vs. soybean cake) on fattening performance and carcass quality of Ouled Djellal lambs (Algeria). rev. Vet, 2014; 165(11-12): 338-343.

5. Chapoutot P., Rouillé B., Sauvant D., Renaud B. Co-products of the agri-food industry: quality food resources not to be INRA Productions Animals 2019; 31(3) :201-220

6. Bara Y, Arbouche R, Arbouche Y, Montaigne E, Baa A, Arbouche F. Effects of replacing corn with cull dates and rumen content extract on production performances and the characteristics of broiler chicken carcasses Ponte - 2019; 75 (8/1): 137-148

7. Baa A, Arbouche F, Arbouche R, Montaigne E, Arbouche $Y$ and Arbouche HS. Effects of incorporating oasis by-products on fattening performance and carcass characteristics of Ouled Djellal lamb, Veterinary World, 2019; 11(10): 13971403

8. Statistics, Ministry of Agriculture and Rural Development 2015; Algeria

9. Sahoo, A., Chaturved, O.H., Thirumurugan, P. and Naqvi, S.M.K. Cactus: ensuring round the year feed Avikanagar: National Innovation in Climate Resilient Agriculture, Central Sheep, and wool Research Institute. 2017; 1-26

10. Inglese, P., Mondragon, C., Queretaro, J., Nefzaoui, A., Saenz, C. Ecology, cultivation, and uses of the Prickly Pear. Publisched by Food and Agriculture Organization of the United Nations (FAO) and the International Centre for 
Agricultural Research in the Dry Areas (ICARDA). 2018; Rome. Italy

https://fr.scribd.com/document/448572718/17628FR

11. Nazareno, M.A. Nutritional properties and medicinal derivative of fruits and cladodes. In Crop Ecology, Cultivation and Uses of Cactus Pear; Inglese, P., Mondragon, C., Nefzaoui, A., Saenz, C., Eds.; FAO: Rome, Italy, 2017; 151-158.

12. Bouzoubaâ, Z., Essoukrati, Y., Tahrouch, S., Hatimi, A., Gharby, , and Harhar, H. (). Phytochemical study of prickly pear from Southern Morocco. J. Saudi Society Agric. Sci., 2016; 15: 155-161.

13. Makkar, H.P.S. Cactus as fodder and beyond. Broadening Horizons. 40, 2017; Available at feedipedia.org (accessed 25 September 2020).

14. De Oliveira, J. P. F., De Andrade Ferreira, M., Alves, M. S. V., De Melo, A. C. C., De Andrade, I. B., Suassuna, J. M. A. and De Lima S.J. Spineless cactus as a replacement for sugarcane in the diets of finishing lambs. Trop. Anim. Health and Prod., 2017; 49(1): 139-144.

15. Cardosoa, D.B., de Carvalhoa, F.F. R., de Medeirosb, G. R., Guima, A., Cabralc, M. D., Verasd, R. M. L., dos Santosa, K. C., Dantasb, L. C. N. and Nascimento, A. G. D. Levels of inclusion of spineless cactus (Nopalea cochenillifera Salm Dyck) in the diet of lambs. Anim. Feed Sci. and Technol., 2019; 247: 23-31.

16. Labra M, Grassi, F., Bardini M., Imazio , Guiggi A., Citterio S., Banfi E., Sgorbati S. Genetic relationships in Opuntia Mill. genus (Cactaceae) detected by molecular marker Plant Science, 2003; 165(5): 1129-1136

17. Nieddu G, De Pau L, Schirra M, D'hallewin G () Chemical composition of fruit and seeds of cactus pears during early and late-induced crop ripening. Acta Horticulturae 1997; 438:105-111

18. L. "Prickly pear, economic importance and technical management ", Bulletin produced at the Agronomic and Veterinary Institute Hassan II, National Program for Technology Transfer in Agriculture (PNTTA), 1998; Rabat, Morocco.

19. Moula N., Humbel M., Leterrier M, Lempereur L., Ait-Kaki A., Touazi L., Saidj D., Hornick J-L. Effects of Opuntia ficusindica on Growth Performance and Serum Parameters of Broiler Chicken in Algeria Tropicultura 2019; 37 (1) https://doi.org/10.25518/2295-8010.263

20. Badr, S.E.A., Fattah, M.S.A. \& Elsaid, A.S. Productive performance and meat quality of commercial Cobb chicken fed diets containing different levels of prickly pear fruits (Opuntia ficus indica) peel. Bull Natl Res Cent 2019; 43, 195 https://doi.org/10.1186/s42269-019-0239-y

21. Ragab, M. S. () Replacing yellow corn with prickly pear peels in growing Japanese quail diets with or without enzyme Fayoum J. Agric. Res. \& Dev., 2007; 21: 97-112.

22. Carpenter K.J., Clegg K.M. The metabolizable energy of poultry feeding stuffs in relation to their chemical composition Sci. Food Agr., 1956; 7: 45-51

23. El Rammouz, R. Study of Post Mortem Biochemical Changes in the Muscle of Poultry - Contribution to the Determinism of the Amplitude of the Decrease in Doctoral thesis, Institut National Polytechnique de Toulouse, 2005; France.

24. Aoac, (Association of Official Analytical Chemists). Official methods of analysis. 18th ed. Arlington: AOAC Int.; 2005

25. Bakr, M.A., El-Boghdady A.M., Hamdy , Shabba H.M. Some Physiological and productive response for rabbit's dosage by extracted peel prickly pear. The 4th Youth Researcher's Conference for Veterinary and Agricultural Science's Sector South Valley University. 3-4 December 2017

26. Ragab, M. S. Effect of partially replacing yellow corn with prickly pear peels on the growth performance of Hy-line W36 male Egyptian J. Nutrition and Feeds, 2012; 15: 361- 373.

27. Hassan F. A., Mobaraz S. M., Basyony M. M., Mahrose M., El-Medany S. A. Effect of using a prickly pear and its byproducts as alternative feed resources on the performance of growing rabbit Egyptian J. Rabbit Science, $2019 ; 29$ (1): 99-124

28. El-Neney B.A.M., Zeedan K.I.I., El-Kotamy E.M., Gad G.G., Abdou Effect of using prickly pear as a source of dietary feedstuffs on productive performance, physiological traits and immune response of rabbit. 2- prickly pear peels

Page $12 / 13$ 
Egyptian J. Nutrition and Feeds, 2019; 22(1): 91-106

29. Islam, M.; Razzaq, A.; Sawsan, H.; Louhaichi, M.; Qamar, I.A.; Rischkowsky, B.A. and Ibrahim, M.N.M. Assessment of different supplemental feeding strategies including cactus (Opuntia ficus-indica) for high sheep productivity in Chakwal, Pakistan. In : The IX International Congress on Cactus Pear and Cochineal "CAM crops for a hotter and dried world", Coquimbo, Chile. 2017

30. Anwar, M. M., and E. M. Sallam. Utilization of prickly pear peels to improve the quality of pan bread. Arab J. Nucl. Sci. and Appl., 2016; 94 (2): 151-163.

31. Zeedan, KH.I.; EL-Neney, B.A.; Abd EL-Latif, A.I.; Awadien, N.B. and Ebeid, T.A. (). Effect of using residues prickly pear as a source of dietary feedstuffs on productive performance, biological traits, and immune response of rabbits. 1- Prickly pear cladodes. Egypt Poultry Sci. J., 2015; 35: 923-943.

32. Abu Shammalah, N. Evaluation of Cactus (Opuntia Sp.) as Forage Source for Growing Rabbits in the Gaza Strip. M.Sc. Thesis, the Islamic Univ. -Gaza, Faculty of Sci. Master of Biological Sci. Palestine. 2007. 